\title{
Some biological aspects of partial starvation. The effect of weight loss and regrowth on body composition in sheep
}

\author{
By J. H. BURTON,* M. ANDERSON† AND J. T. REID \\ Department of Animal Science, Morrison Hall, Cornell University, \\ Ithaca, New York, USA
}

(Received 3 December 1973 - Accepted I 5 February 1974)

\begin{abstract}
I. A study of the effects of four dietary treatments on body-weight and the water, protein, fat and energy content of the empty bodies of forty-three Suffolk ewes is reported. The treatments were as follows: $T_{1}$, ad lib. food intake from a full-body-weight (FBW) of $40 \mathrm{~kg}$ to $7 \mathrm{Ig}$; $\mathrm{T}_{2}$, partial fasting with a resulting weight loss from $7 \mathrm{I} \mathrm{kg}$ to $5 \circ \mathrm{kg} \mathrm{FBW}$; $\mathrm{T}_{3}$, realimentation and regrowth from $50 \mathrm{~kg}$ to $7 \mathrm{r} \mathrm{kg} \mathrm{FBW;} \mathrm{T}_{4}$, a slight food restriction producing a reduced growth rate from $40 \mathrm{~kg}$ to $50 \mathrm{~kg} \mathrm{FBW}$ followed by ad lib. food intake from $50 \mathrm{~kg}$ to $7 \mathrm{I} \mathrm{kg}$ FBW. On all treatments sheep were slaughtered in groups of three at $7 \mathrm{~kg}$ intervals between $50 \mathrm{~kg}$ and $7 \mathrm{Ig} \mathrm{FBW}$.

2. The whole body, with the exception of several body organs and glands, wool and the contents of the gastrointestinal tract, was minced and analysed for water, protein, fat and energy. Adipose tissue samples were removed at slaughter from subcutaneous and internal fat depots for histological examination. Regression analysis was used in comparing treatment effects on body composition.

3. No significant differences were observed between the results of $T_{1}$ and $T_{4}$. In consequence these results were pooled and are referred to as $T_{1}$. At $40 \mathrm{~kg}$ FBW the empty (ingesta-free) bodies of the lambs contained approximately $52 \%$ water, $14 \%$ protein and $29 \%$ fat. Through normal growth to $7 \mathrm{I} \mathrm{kg} \mathrm{FBW}$ on $\mathrm{T}_{1}$ these values had changed to $40, \mathrm{II}^{\prime} 5$ and $45 \%$, respectively. Following weight loss to $50 \mathrm{~kg} \mathrm{FBW}$ on $\mathrm{T}_{2}$ the water, protein and fat contents of the empty bodies were $47,13.5$ and $35 \%$, respectively. Regrowth on $T_{3}$ to $7 \mathrm{x} \mathrm{kg} \mathrm{FBW}$ resulted in little change in these components, the respective values being 46, I3 and $36 \%$. The sheep which had undergone weight loss and regrowth retained significantly more water and less energy than normally grown controls and tended to deposit less fat and more protein.

4. Gastrointestinal tract contents accounted for II \% of FBW at $7 \mathrm{I} \mathrm{kg}$ in $\mathrm{T}_{3}$ animals. In $\mathrm{T}_{1}$, the value was $7^{*} \mathrm{I} \%$ at a similar FBW. Thus there was an average increase of over $56 \%$ in contents in the realimented animals.

5. Mean adipocyte diameter at $50 \mathrm{~kg}$ FBW on $\mathrm{T}_{1}$ was $\mathrm{I}_{34} \pm 3 \mu \mathrm{m}$. At $7 \mathrm{I} \mathrm{kg} \mathrm{FBW}$ the mean diameter had increased to $152 \pm 9 \mu \mathrm{m}$. Weight reduction $\left(\mathrm{T}_{2}\right)$ and regrowth $\left(\mathrm{T}_{8}\right)$ resulted in mean diameters of $122 \pm 4 \mu \mathrm{m}$ and $143 \pm 4 \mu \mathrm{m}$ at $50 \mathrm{~kg}$ and $7 \mathrm{I} \mathrm{kg} \mathrm{FBW,} \mathrm{respectively.}$
\end{abstract}

The ruminant animal has been found to have a comparatively rigid relationship between its body size as measured by weight and the weight of each of the body components: water, fat, protein and energy (Tulloh, 1963; Reid, Bensadoun, Bull, Burton, Gleeson, Han, Joo, Johnson, McManus, Paladines, Stroud, Tyrrell, Van Niekerk \& Wellington, I968). Meal frequency, dietary energy input levels, protein: energy ratio, and age have all been found to exert little effect on these components in animals maintained in positive balance when they have been regressed on either fullbody-weight (FBW) or empty-body-weight (EBW) (Reid et al. 1968; Burton \& Reid, I969). Recently, however, other workers (Ørskov, McDonald, Fraser \& Corse, I97I) have indicated that the level of dietary protein available to the growing animal may

* Present address: Department of Nutrition, University of Guelph, Guelph, Ontario, Canada.

† Present address: National Institute for Research in Dairying, Shinfield, Reading, England. 
have an effect on the protein content of the body, particularly in the earlier stages of growth. The projection of their results beyond the measured values indicates that the effects observed at 27.5 and $40 \mathrm{~kg}$ live weight would disappear at body-weights of $45-47 \mathrm{~kg}$.

The stability of these relationships has enabled workers to evolve a series of equations by which changes in body composition can be estimated from body-weight or density (Reid, Wellington \& Dunn, 1955; Lofgreen \& Otagaki, I960). This has, naturally, permitted a much more critical evaluation of nutritional treatments than was possible using changes in body-weight alone. Reid et al. (1968) have indicated, however, that when ruminants are restricted to a submaintenance intake and subsequently regrown there is a change in the relationship of the body components to body-weight. Body fat and water appear to be most critically affected, with some controversy as to the manner in which these effects are manifested. Wilson \& Osbourn (I960) and Meyer \& Clawson (1964) found an increase in the percentage of fat in the carcasses of restricted and realimented animals when compared with controls. In sheep (Reid et al. 1968; McManus, Reid \& Donaldson, I972) rats (Robinson \& Lambourne, 1970) and humans (Barnard, Ford, Garnett, Mardell \& Whyman, I969) a decrease in fat content and an increase in water content of the animal body has been demonstrated in fasted-refed treatments when compared with control animals maintained in positive energy balance. Protein accretion has also been reported to be greater in the fasted-refed treatments in some of these studies (Reid et al. 1968; Barnard et al. 1969; McManus et al. 1972). These apparent contradictions may possibly be due to the severity of the dietary restrictions imposed.

Part of this study was an attempt to quantify and describe the changes in water, fat, protein and energy in the whole bodies of sheep which are due to slight and severe food restrictions followed by realimentation.

\section{EXPERIMENTAL}

\section{Animals}

Forty-four Suffolk ewe lambs were used in the experiment; forty-two were randomly assigned to fourteen groups on four treatments before reaching a body-weight of $40 \mathrm{~kg}$. The remaining two lambs were slaughtered at a FBW of $40 \mathrm{~kg}$.

\section{Treatments}

The treatments, illustrated in Fig. $I$, were as follows: $T_{1}$, thirty lambs were fed ad lib., permitting maximum rate of growth from an initial wool-free FBW of $4^{\circ} \mathrm{kg}$ to a final wool-free FBW of $7 \mathrm{I} \mathrm{kg}$. Twelve lambs were slaughtered in groups of three at $50,57,64$ and $7 \mathrm{I} \mathrm{kg} \mathrm{FBW} \mathrm{(groups} \mathrm{I}-4$ ); $\mathrm{T}_{2}$, the remaining eighteen sheep were given a submaintenance ration and remained on this intake until they reached $50 \mathrm{~kg}$ FBW with the exception of six which were slaughtered at $64 \mathrm{~kg}$ and $57 \mathrm{~kg} \mathrm{FBW}$ (groups 5 and 6). Three were also slaughtered at $50 \mathrm{~kg}$ FBW before realimentation was begun (group 7); $\mathrm{T}_{3}$, realimentation was begun on the remaining nine animals with the slaughter of groups of three animals, during regrowth, 


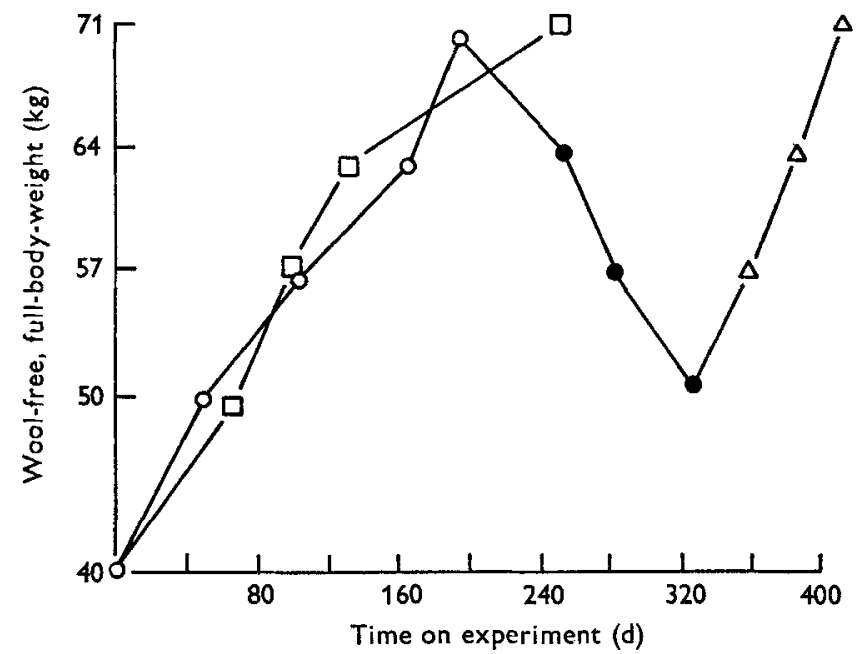

Fig. I. The experimental design showing the no. of $d$ required for each group to reach its respective slaughter weight. $T_{1}$, groups $I-4(O), I^{-1}-1_{4}(\square)$, in positive energy balance from $40 \mathrm{~kg}$ to $7 \mathrm{Ig}$ full-body-weight (FBW) or until slaughtered; $\mathrm{T}_{2}$, groups $5-7(\mathcal{O})$, in positive energy balance until $7 \mathrm{r} \mathrm{kg}$ FBW then partially starved with a resulting weight loss to $5 \circ \mathrm{kg}$ FBW or until slaughtered; $T_{3}$, groups $8-1 \circ(\triangle)$, in positive energy balance until $7 \mathrm{I} \mathrm{kg} \mathrm{FBW}$, in negative energy balance until $50 \mathrm{~kg}$ FBW then realimented and regrown to $7 \mathrm{I} \mathrm{kg} F \mathrm{FW}$ or until slaughtered.

occurring at the same FBW as on previous treatments $(57,64$ and $7 \mathrm{I} \mathrm{kg} F \mathrm{FW}$, groups 8-10); $\mathrm{T}_{4}$, this treatment involved twelve lambs fed at a slightly restricted level from $40 \mathrm{~kg}$ to $50 \mathrm{~kg} \mathrm{FBW}$, at which weight three were slaughtered (group I I). The remaining nine lambs were switched to an $a d l i b$. ration and groups of three were slaughtered at 57,64 and $7 \mathrm{Ig} \mathrm{FBW}$ (groups $12-14$ ).

\section{Management}

As the animals reached a FBW of $40 \mathrm{~kg}$ they were shorn and a wool-free FBW was recorded. This wool was discarded. From this time until slaughter the sheep were housed in individual pens from which faeces and urine could be collected when required.

The diet to which the lambs were accustomed before starting the experiment was used in all treatments throughout the experiments. Rations were fed in three equal portions at $08.00,12.00$ and 16.00 hours. Any uneaten food from the previous day was removed prior to the 08.00 hours feeding. Rations were weighed daily and adjustments in quantity made on a weekly basis according to weight changes or food refusals.

When sheep were switched from $\mathrm{T}_{1}$ to $\mathrm{T}_{2}$ the reduction in the rations was made gradually until a minimum intake of $12 \mathrm{~g}$ dry matter $(\mathrm{DM}) / \mathrm{kgFBW}^{0 \cdot 75}$ per $\mathrm{d}$ was reached. Similarly, when the sheep undergoing realimentation were changed from $\mathrm{T}_{2}$ to $\mathrm{T}_{3}$, the rations were increased in a stepwise fashion until they were slaughtered or ad lib. levels were reached. 


\section{Diet}

One pelleted, complete diet was fed in all treatments. This diet consisted of $(\mathrm{g} / \mathrm{kg})$ : ground maize 600, soya-bean meal I40, ground lucerne hay I90, molasses 50 , mineral mixture 5, vitamin mixture 5 , lignin sulphate 10 . The crude protein and gross energy concentrations (per $\mathrm{kg} \mathrm{DM}$ ) were $\mathrm{r} 80 \mathrm{~g}$ and $\mathrm{s} 8.54 \mathrm{MJ}$ respectively.

\section{Slaughter and sampling procedures}

At $24 \mathrm{~h}$ prior to slaughter each sheep was shorn and a final wool-free FBW was recorded. At 07.00 hours on the day of slaughter one-third of the ration was given and any food remaining at 08.00 hours was removed and recorded. All animals were slaughtered between 10.00 and 11.00 hours on the designated day.

The slaughter procedure was that used by Paladines, Reid, Bensadoun \& Van Niekerk ( 1964 ) with the following modifications: the adrenals, kidneys, liver, pancreas and thyroid were removed, weighed and stored frozen in sealed plastic bags for further histological study and analysis. Approximately $5 \mathrm{~g}$ of adipose tissue were removed from a subcutaneous fat depot at the base of the tail and from an internal, perirenal depot for histological examination. Following the removal of the alimentary tract contents the carcass, including the alimentary tract, was minced and a portion kept for analysis (Paladines et al. I964). Empty-body weight (ingesta-free) was obtained by subtracting the weight of the gastrointestinal tract contents from the FBW.

\section{Wool}

The total weight of wool produced during the experiment was recorded for each animal and a portion retained for analysis. Wool data were not included in those used for the computation of body composition regression equations.

\section{Adipose tissue}

The determination of average adipocyte size and number in animals of various groups was done using the method of Hirsch \& Gallian (I968) with minor modifications. The adipose tissue samples removed at slaughter were immediately weighed, put into small, sealed containers and frozen rapidly in a solid $\mathrm{CO}_{2}$-acetone mixture. As soon as possible, the sample was treated in the following manner: tissue shreds weighing between 100 and I $50 \mathrm{mg}$ were cut from the still-frozen blocks and washed thoroughly with warm isotonic saline on weighed, circular disks of nylon screen (pore size, $250 \mu \mathrm{m}$ ). These disks were about $50 \mathrm{~mm}$ in diameter and had been washed in 2: I $(\mathrm{v} / \mathrm{v})$ chloroform-methanol and air-dried before being weighed. The filter disks and tissue slices were then rapidly blotted with absorbent paper to remove excess moisture and weighed.

The nylon screen and tissue were then immediately placed in glass jars containing $25 \mathrm{ml}$ of a solution of $20 \mathrm{~g}$ osmium tetroxide in $110.05 \mathrm{M}$-collidine- $\mathrm{HCl}$ buffer at $\mathrm{pH} 7 \cdot 4$. Fixation was allowed to continue for $72-90 \mathrm{~h}$ at $37^{\circ}$. At the end of this time, the contents of the jar were washed through nylon screening with a pore size of $25^{\circ} \mu \mathrm{m}$ 
Table I. Mean dry matter intakes (DMI) and growth rates of sheep during treatment intervals when they were fed ad lib. $\left(T_{1}\right)$, at submaintenance level $\left(T_{2}\right)$ or during realimentation $\left(T_{3}\right)$

(Mean values with their standard errors)

\begin{tabular}{|c|c|c|c|c|c|c|c|}
\hline \multirow[b]{2}{*}{ Treatment* } & \multirow{2}{*}{$\begin{array}{c}\text { Initial } \\
\text { weight } \\
\text { (kg) }\end{array}$} & \multirow{2}{*}{$\begin{array}{c}\text { Final } \\
\text { weight } \\
(\mathrm{kg})\end{array}$} & \multicolumn{2}{|c|}{$\begin{array}{c}\text { DMI } \\
\left(\mathrm{g} / \mathrm{kgFBW}^{\mathrm{D} \cdot 75} \text { per } \mathrm{d}\right)\end{array}$} & \multicolumn{2}{|c|}{$\begin{array}{l}\text { Growth rate } \\
\quad(\mathrm{g} / \mathrm{d})\end{array}$} & \multirow{2}{*}{$\begin{array}{c}\text { No. of } \\
\text { observations }\end{array}$} \\
\hline & & & Mean & $\mathrm{SE}$ & Mean & $\mathrm{SE}$ & \\
\hline $\mathrm{T}_{1}$ & $\begin{array}{l}40 \\
50\end{array}$ & $\begin{array}{l}5^{\circ} \\
7 \mathrm{r}\end{array}$ & $\begin{array}{l}63 \\
55\end{array}$ & $\begin{array}{l}\mathrm{x} \cdot 0 \\
\mathrm{I} \cdot 5\end{array}$ & $\begin{array}{l}x 90 \\
161\end{array}$ & $\begin{array}{l}7 \cdot 3 \\
\text { II }\end{array}$ & $\begin{array}{l}41 \\
24\end{array}$ \\
\hline $\mathrm{T}_{2}$ & 71 & 50 & I5 & 0.14 & -159 & $7 \cdot 8$ & 12 \\
\hline $\mathrm{T}_{3}$ & 50 & $7 \mathrm{I}$ & 50 & 0.38 & 243 & 14 & 3 \\
\hline
\end{tabular}

using distilled water. Cells were freed from connective tissue by gently rubbing the shreds by hand while continuing the washing. The loose cells went through the nylon screening and were trapped in a beaker. The contents of the beaker were then poured onto nylon screening with a $25 \mu \mathrm{m}$ pore size, which retained the adipocytes, washed with distilled water to free them of any debris smaller than $25 \mu \mathrm{m}$ and flushed into a weighed $400 \mathrm{ml}$ beaker using filtered isotonic saline. The density of this suspension was approximately the same as the density of the saline, therefore the measured density of the saline at room temperature was used to determine the volume of the cell suspension.

A Coulter Counter fitted with a $560 \mu \mathrm{m}$ aperture tube and a $2 \mathrm{ml}$ manometer was then used to determine cell size and numbers per $\mathrm{g}$ tissue.

\section{RESULTS}

One of the lambs in group $\mathrm{I} 2$ became ill and had to be removed from the experiment; consequently there are results from two animals only in this group.

When differences among treatment effects on body composition were investigated, it was found that there were no differences between $T_{1}$ and $T_{4}$ results. Since the animals on these two treatments were in continuous positive energy balance and the differences in average food intakes were not great $\left(68\right.$ and $5^{6} \mathrm{~g} / \mathrm{kgFBW}{ }^{0.75}$ for $\mathrm{T}_{1}$ and $\mathrm{T}_{4}$ respectively), the results from these treatments were pooled and presented as $T_{1}$.

\section{Food intake and growth rate}

Food intake and growth rate results for all animals completing the total growth or weight loss interval of a treatment are presented in Table I. Results from all forty-one animals completing the experiment were used in calculating the food intake value of $63 \pm \mathrm{r} \cdot 0 \mathrm{~g} / \mathrm{kgFBW} W^{0.75}$ per $\mathrm{d}$ and the growth rate of $190 \pm 7 \cdot 3 \mathrm{~g} / \mathrm{d}$ for the interval from $40 \mathrm{~kg} \mathrm{FBW}$ to $50 \mathrm{~kg} \mathrm{FBW}$. Food intake $\left(55 \pm \mathrm{r}^{\cdot} 5 \mathrm{~g} / \mathrm{kgFBW} \mathrm{W}^{0.75}\right.$ per d) and growth rates $(\mathbf{I} 6 \mathbf{I} \pm \mathbf{I 0} .8 \mathrm{~g} / \mathrm{d})$, as was expected, were significantly lower $(P<0.05)$ during growth 
Table 2. Relationships between $\log _{10}$ of the body components or energy ( $\mathrm{Y}$ ), and the $\log _{10}$ of empty-body-weight $(\mathrm{X})$

\begin{tabular}{|c|c|c|c|c|c|}
\hline \multirow[b]{2}{*}{ Component } & \multirow[b]{2}{*}{ Treatment* } & \multicolumn{2}{|c|}{$\begin{array}{c}\text { In equation: } \log Y= \\
b \log X+\log a\end{array}$} & \multirow[b]{2}{*}{$r^{2}$} & \multirow[b]{2}{*}{$100 S y \times x$} \\
\hline & & $b$ & $\log a$ & & \\
\hline Water (kg) & $\begin{array}{l}\mathrm{T}_{1} \\
\mathrm{~T}_{2} \\
\mathrm{~T}_{3}\end{array}$ & $\begin{array}{l}0.5211 \\
0.4038 \\
0.9109\end{array}$ & $\begin{array}{r}0.4864 \\
0.6668 \\
-0.1701\end{array}$ & $\begin{array}{l}0.658 \\
0.650 \\
0.911\end{array}$ & $\begin{array}{l}3 \cdot 11 \\
I \cdot 47 \\
1 \cdot 57\end{array}$ \\
\hline Protein (kg) & $\begin{array}{l}T_{1} \\
T_{2} \\
T_{3}\end{array}$ & $\begin{array}{l}0.6376 \\
0.5285 \\
0.8599\end{array}$ & $\begin{array}{l}-0.2651 \\
-0.08251 \\
-0.6245\end{array}$ & $\begin{array}{l}0.790 \\
0.804 \\
0.844\end{array}$ & $\begin{array}{l}2 \cdot 72 \\
1 \cdot 29 \\
2 \cdot 03\end{array}$ \\
\hline Fat $(\mathrm{kg})$ & $\begin{array}{l}T_{1} \\
T_{2} \\
T_{3}\end{array}$ & $\begin{array}{l}I \cdot 766 \\
I \cdot 903 \\
I \cdot 172\end{array}$ & $\begin{array}{l}-I \cdot 75^{8} \\
-I \cdot 959 \\
-0.759\end{array}$ & $\begin{array}{l}0.911 \\
0.955 \\
0.817\end{array}$ & $\begin{array}{l}4 \cdot 57 \\
2 \cdot 04 \\
3 \cdot 04\end{array}$ \\
\hline Energy (MJ) & $\begin{array}{l}T_{1} \\
T_{2} \\
T_{3}\end{array}$ & $\begin{array}{l}I \cdot 582 \\
I \cdot 710 \\
I \cdot 120\end{array}$ & $\begin{array}{l}-0.9960 \\
-I .1903 \\
-0.22 I 4\end{array}$ & $\begin{array}{l}0.931 \\
0.956 \\
0.898\end{array}$ & $\begin{array}{l}3.57 \\
1.81 \\
2.07\end{array}$ \\
\hline
\end{tabular}

from $50 \mathrm{~kg}$ to $7 \mathrm{rg} \mathrm{kBW}$. An average food intake of $\mathrm{x}_{5} \pm 0.14 \mathrm{~g} / \mathrm{kgFWB} \mathrm{F}^{0.75}$ per $\mathrm{d}$ was

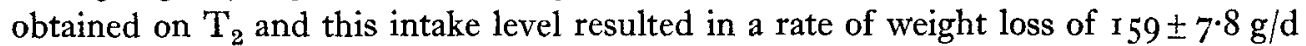
which was approximately equal to the rate of weight gain over the same interval on $\mathrm{T}_{1}$. Realimentation on $\mathrm{T}_{3}$ produced a significantly higher $(P<0.05)$ growth rate $(243 \pm 14.0 \mathrm{~g} / \mathrm{d})$ on a lower average food intake level $\left(50 \pm 0.38 \mathrm{~g} / \mathrm{kgFBW}{ }^{0.75}\right.$ per d).

The average number of $d$ required by each group to reach its respective slaughter weight is illustrated in Fig. $r$. The compensatory nature of the growth on $\mathrm{T}_{3}$ may also be seen in this figure. The animals on $\mathrm{T}_{3}$ regained the $2 \mathrm{I} \mathrm{kg}$ of body-weight which had been lost on $\mathrm{T}_{2}$ in less than half the time required to gain a similar amount of weight on $\mathrm{T}_{1}$.

\section{Body composition}

The results obtained from the slaughter and analysis of the complete empty bodies were used to obtain the regression equations presented in Table 2. The allometric equation $Y=a X^{b}$, in logarithmic form, where $Y$ is body component (kg) or body energy (MJ) and $X$ is empty-body-weight $(\mathrm{kg})$, gave the best fit to the results and is the form presented in this table.

Water. The water content of the empty body as affected by the treatments is graphically presented in Fig. 2(a). Each point in this figure (and in Fig. 2(b), (c) and $(d)$ ) is a mean value for results from three sheep with the exceptions of the initial group and group 12 which have two sheep each. The average water content of the animals on $\mathrm{T}_{3}$ was higher than those on other treatments at similar FBW. Inspection of the regression coefficients from the equations in Table 2 relating water to EBW reveals that the rate of water retention was greatest for the animals on $\mathrm{T}_{3}$. This coefficient is significantly larger $(P<0.05)$ than the remaining two. The regression coefficient from the equation for $\mathrm{T}_{2}$ indicates a lower rate of water loss during partial 

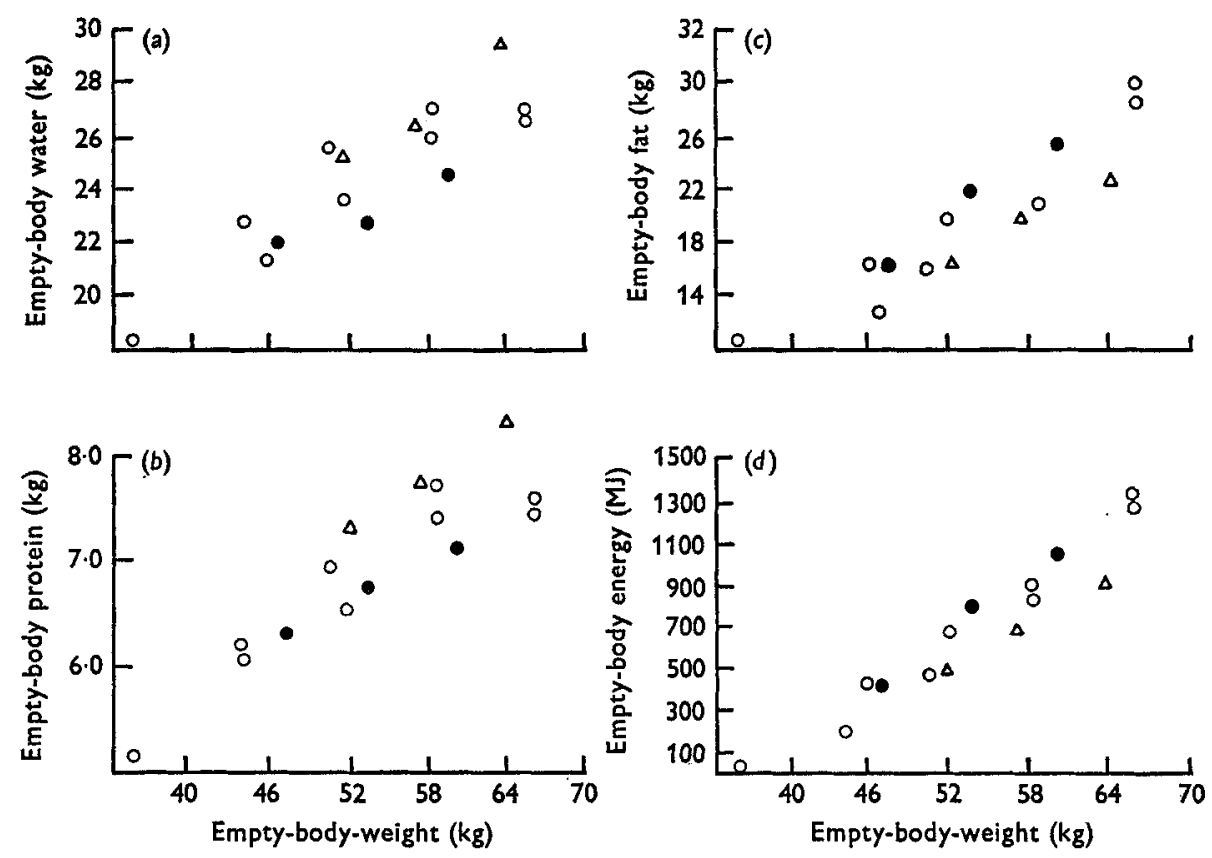

Fig. 2. Relationships between empty-body-weight and (a) empty-body water, (b) emptybody protein, (c) empty-body fat and $(d)$ empty-body energy for $T_{1}$, normal growth (O); $\mathrm{T}_{2}$, normal growth followed by weight loss $(0) ; \mathrm{T}_{3}$, normal growth followed by weight loss followed by regrowth $(\Delta)$.

starvation than water retention during normal growth $\left(\mathrm{T}_{1}\right)$. The difference was not statistically significant, however.

Protein. The treatment effects on empty-body protein shown in Fig. $2(b)$ were similar to the effects on water content. At similar weights the empty bodies of the partially fasted, refed animals $\left(\mathrm{T}_{3}\right)$ contained more protein than the controls. The results in Table 3 support this conclusion as the weight of protein in the $T_{3}$ groups (groups 8,9 and $x 0$ ) is greater than that in other treatment groups at similar weights. However, when these apparent differences were examined in an analysis of variance, none was found to be significant. An examination of the regression coefficients of the equations relating protein content to EBW (Table 2) shows an increased rate of protein retention in the animals on $\mathrm{T}_{3}$; this coefficient was significantly different from the coefficient for $\mathrm{T}_{1}(P<0 \cdot \mathrm{I})$. As with water, there was an apparent tendency for protein to be depleted more slowly during weight loss $\left(\mathrm{T}_{2}\right)$ than it was retained during normal growth.

Fat and energy. Fig. $2(c$ and $d)$ presents the treatment effects on empty-body fat and energy, both of which were affected in a similar manner. The regression coefficient in Table 2 relating the change in fat content to the change in EBW for $T_{3}$ shows a reduced rate of fat accumulation when compared with the control rate $\left(\mathrm{T}_{1}\right)$; the difference was significant $(P<0.06)$. According to the regression coefficient for $\mathrm{T}_{2}$, partially starved animals tended to utilize fat more rapidly than it was deposited 
Table 3. Wool-free, empty-body composition of groups of sheep fed ad lib. (1-4), at submaintenance level (5 and 6), during realimentation (8-10) or fed at slightly restricted level (II) then ad lib. (I2-I4)

\begin{tabular}{|c|c|c|c|c|c|c|c|c|}
\hline $\begin{array}{c}\text { Group* } \\
\text { no. }\end{array}$ & $\begin{array}{l}\text { FBW } \\
(\mathrm{kg})\end{array}$ & $\begin{array}{l}\text { EBW } \\
\text { (kg) }\end{array}$ & $\begin{array}{c}\text { Dry } \\
\text { matter } \\
(\mathrm{kg})\end{array}$ & $\begin{array}{c}\text { Water } \\
(\mathrm{kg})\end{array}$ & $\begin{array}{l}\text { Protein } \\
\text { (kg) }\end{array}$ & $\begin{array}{l}\text { Diethyl } \\
\text { ether } \\
\text { extract } \\
(\mathrm{kg})\end{array}$ & $\begin{array}{l}\text { Ash } \\
(\mathrm{kg})\end{array}$ & $\begin{array}{l}\text { Energy } \\
\text { (MJ) }\end{array}$ \\
\hline In & $40 \cdot I$ & $35^{\cdot} 8$ & $\mathrm{I} 7 \cdot 2$ & r $8 \cdot 6$ & $5 \cdot 12$ & 10.4 & $I \cdot 35$ & 536 \\
\hline I & $49 \cdot 8$ & $45^{\cdot 6}$ & $24 \cdot 2$ & $2 I \cdot 4$ & $6 \cdot 16$ & $16 \cdot 3$ & $I \cdot 47$ & 799 \\
\hline 2 & $56 \cdot 5$ & $50 \cdot 6$ & 25.0 & $25 \cdot 6$ & 6.92 & 16.4 & $I \cdot 44$ & 808 \\
\hline 3 & $63 \cdot 4$ & $58 \cdot 5$ & $32 \cdot 7$ & 25.8 & $7 \cdot 43$ & $22 \cdot 9$ & I.9I & 1105 \\
\hline 4 & $70 \cdot 0$ & 65.5 & $39^{\circ} I$ & $26 \cdot 4$ & $7 \cdot 57$ & $28 \cdot 9$ & 2.09 & r 338 \\
\hline 5 & $64 \cdot 0$ & $59^{\cdot 6}$ & 35.2 & 244 & $7 \cdot 14$ & 25.9 & $I .7 x$ & 1201 \\
\hline 6 & 57.5 & $53 \cdot 3$ & $30 \cdot 5$ & $22 \cdot 8$ & 6.77 & $21 \cdot 9$ & $x \cdot 69$ & 1046 \\
\hline 7 & $50 \cdot 3$ & $46 \cdot 8$ & 24.7 & $22 \cdot 1$ & $6 \cdot 34$ & $16 \cdot 4$ & $I \cdot 79$ & 799 \\
\hline 8 & $57 \cdot 7$ & $5 I \cdot 6$ & $26 \cdot 3$ & $25 \cdot 3$ & $7 \cdot 32$ & 16.6 & $I \cdot 89$ & 836 \\
\hline 9 & $64 \cdot 3$ & $57^{\circ} 0$ & 30.4 & $26 \cdot 6$ & $7 \cdot 68$ & 20.1 & 2.08 & 975 \\
\hline I0 & 714 & 63.5 & 34.0 & $29 \cdot 6$ & $8 \cdot 33$ & $22 \cdot 9$ & 2.02 & I I 13 \\
\hline I I & $49^{\circ} \mathrm{I}$ & 43.7 & 20.8 & $22 \cdot 9$ & $6 \cdot 11$ & $12 \cdot 8$ & $I \cdot 47$ & 657 \\
\hline 12 & $57 \cdot 2$ & $5 I \cdot 6$ & $28 \cdot 0$ & $23^{\cdot 6}$ & $6 \cdot 5^{8}$ & 19.7 & $I \cdot 34$ & 954 \\
\hline$r_{3}$ & $63 \cdot 7$ & $58 \cdot 3$ & $3 I \cdot 3$ & 27.0 & 7.67 & $2 I \cdot 2$ & I.96 & 1025 \\
\hline 14 & $71 \cdot 2$ & 65.8 & $40 \cdot r$ & 25.7 & $7 \cdot 49$ & 30.5 & $\mathrm{I} \cdot 82$ & 1402 \\
\hline $\mathrm{SE}$ & 0.47 & 0.76 & $0.9 \mathrm{r}$ & 0.70 & 0.23 & 0.96 & O.I 3 & $38 \cdot 2$ \\
\hline
\end{tabular}

FBW, full-body-weight; EBW, empty-body-weight.

* Initial group (In) and group iz have two animals each, all others have three animals. For details of treatments see p. 516 .

Table 4. Gastrointestinal contents as a percentage of full-body-weight for groups of sheep fed ad lib. ( $\mathrm{x}-4)$, at submaintenance level (5 and 6), during realimentation (8-10) or fed at slightly restricted level (I I) then ad lib. (12-14)

(Mean values with their standard errors)

\begin{tabular}{|c|c|c|c|c|c|c|c|c|c|c|c|c|c|c|}
\hline Group no. & I & 2 & 3 & 4 & 5 & 6 & 7 & 8 & 9 & 10 & I I & 12 & 13 & 14 \\
\hline $\begin{array}{l}\text { Contents }(\%) \\
\text { SE }\end{array}$ & $\begin{array}{l}8 \cdot 4 \\
0 \cdot 75\end{array}$ & $\begin{array}{c}10 \cdot 4 \\
1 \cdot 62\end{array}$ & $\begin{array}{l}7 \cdot 7 \\
1 \cdot 80\end{array}$ & $\begin{array}{l}6.5 \\
0.44\end{array}$ & $\begin{array}{l}6.9 \\
1.42\end{array}$ & $\begin{array}{l}7 \cdot 2 \\
1 \cdot 28\end{array}$ & $\begin{array}{l}7 \cdot 0 \\
0 \cdot 74\end{array}$ & $\begin{array}{l}10.5 \\
0.90\end{array}$ & $\begin{array}{l}\text { II } \cdot 2 \\
1 \cdot 07\end{array}$ & $\begin{array}{l}\text { II I I } \\
I \cdot I 7\end{array}$ & $\begin{array}{l}I I \cdot 0 \\
I \cdot 62\end{array}$ & $\begin{array}{l}9.9 \\
0.93\end{array}$ & $\begin{array}{l}8 \cdot 6 \\
1 \cdot 47\end{array}$ & $\begin{array}{l}7.7 \\
0.69\end{array}$ \\
\hline
\end{tabular}

during normal growth. Similar treatment differences are reflected in the regression coefficients of the energy equations in Table 2 with the realimented animals of $T_{3}$ retaining less energy per kg EBW increase than the normally grown controls $\left(\mathrm{T}_{1}\right)$.

Contents of the gastrointestinal tract. Group means for gastrointestinal contents expressed as a percentage of FBW are presented in Table 4. The lightest contents were found in $T_{2}$, for which the average was $7 \cdot 0 \pm 0 \cdot 1 \%$. The largest amounts relative to body size were in $\mathrm{T}_{3}$ animals where the mean value was $10.9 \pm 0.2 \%$. This value was an increase of $24 \%$ over that of $8 \cdot 8 \pm 0.6 \%$ obtained in $\mathrm{T}_{1}$ animals.

Adipocyte size and numbers. In $\mathrm{T}_{1}$ the average sizes of adipose tissue cells were found to be $134 \pm 3 \mu \mathrm{m}$ and $152 \pm 9 \mu \mathrm{m}$ at $50 \mathrm{~kg}$ and $7 \mathrm{r} \mathrm{kg} \mathrm{FBW}$, respectively. This difference in size was significant $(P<0.05)$. Weight reduction in $\mathrm{T}_{2}$ was accompanied by a decrease in cell size to an average diameter of $122 \pm 4 \mu \mathrm{m}$ at $50 \mathrm{~kg}$ FBW. This value was not statistically different from that obtained for $T_{1}$ animals at the 


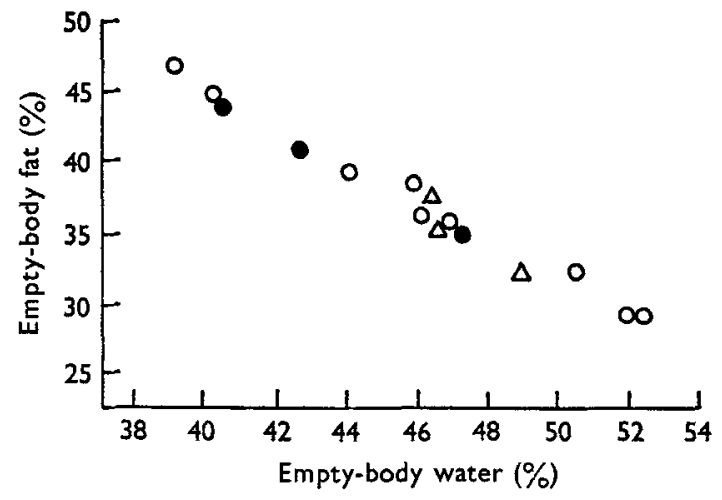

Fig. 3. The relationship between the percentages of water and fat in the empty body for all treatments. $T_{1}$, normal growth (O); $T_{2}$, normal growth followed by weight loss $(0) ; T_{3}$, normal growth followed by weight loss followed by regrowth $(\triangle) . \quad Y=-0.779 X+74 \cdot 8$; Sy $\times x=0.819$.

same FBW. Regrowth to $7 \mathrm{rg}$ FBW in $\mathrm{T}_{3}$ was associated with an increase in size and a mean diameter of $143 \pm 4 \mu \mathrm{m}$ which was not statistically different from ${ }^{2} 5^{2} \mu \mathrm{m}$ obtained in $\mathrm{T}_{1}$.

No significant treatment effect on adipose cell numbers was observed. The mean value obtained was $3.9 \pm 0.5 \times 10^{5}$ cells per $g$ tissue.

\section{DISCUSSION}

Some basic tenets for the prediction of the chemical composition of the animal body have been set out by Reid et al. (1955) and Reid, Bensadoun, Paladines \& Van Niekerk (1963). These workers have found highly predictable relationships between the various components and body-weight in animals maintained in positive energy balance. Before these prediction equations can be used for analysing the composition of weight changes in animals which have undergone partial starvation, further com positional data on such animals must be obtained.

The treatments imposed in this study have apparently decreased the $r^{2}$ values (Table 2) slightly from previous high values (Reid et al. 1968). One possible explanation for the increase in variability of results in this study may be the fact that no standard reducing period was imposed on these animals before slaughter. Food and water were available to all animals until shortly before they were slaughtered and may have affected at least the empty-body water content. The $r^{2}$ values remain sufficiently large, however, to make the proposed scheme useful in predicting changes in body components in animals which have undergone weight loss and regrowth. Variation in the results was least in the $T_{3}$ animals for water and protein and only slightly greater than that of the other treatments for fat and energy.

An important requirement of the design for the resolution of the body components is the ability to predict accurately body fat if body water is known or vice versa. Since water and fat are the variables affected most by $\mathrm{T}_{2}$ and $\mathrm{T}_{3}$, the question arose of whether their normally high correlation had been affected by the treatments. Fig. 3 indicates 


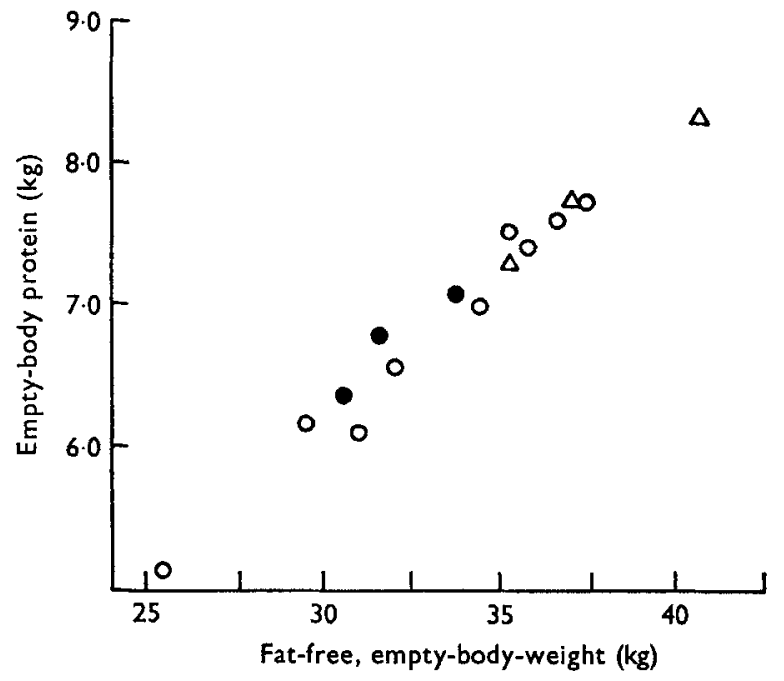

Fig. 4. The relationship between fat-free, empty-body-weight and empty-body protein for all treatments. $T_{1}$, normal growth $(O) ; T_{2}$, normal growth followed by weight loss (O); $T_{3}$, normal growth followed by weight loss followed by regrowth $(\triangle) . Y=0.211 X-0.13 I$; Sy $\times x=0.527$.

that the predictive value of this relationship is unaffected by treatment and is rectilinear over the weight range studied. This relationship has been shown to be curvilinear (Reid et al. 1955; Reid et al. 1963) but the results of this study do not represent a sufficiently wide range for curvilinearity to be estimated. This figure also shows that the partially fasted, refed animals in $\mathrm{T}_{3}$ had percentages of empty-body water and fat which were similar to normally grown animals IO-I 2 kg lighter in FBW.

The continuously grown animals of $T_{1}$ are considerably fatter than would be expected from other studies on the Suffolk breed. Equations presented by Reid et al. (1968) indicate that at $50 \mathrm{~kg}$ EBW the empty body should contain about $13.2 \mathrm{~kg}$ fat. In this study an actual fat content of approximately $17.5 \mathrm{~kg}$ was found, a value $32.5 \%$ higher than that found in the former work. The sheep used in the present study were females, whereas the previous results are for male castrates. It is not known what the difference in fat content would be between these two sexes of animals on the same diet but results from a study by Bull ( 1969 ) show an increased fatness of the Southdown ewe over the ram, given similar diets, of at least $29 \%$.

In recent work Andrews \& Ørskov (1970) have reported increases of approximately $20 \%$ in the fat contents of empty bodies of female sheep when compared to males of similar breeds given similar rations and slaughtered at the same live weight. The increased fatness of the females used in the present study may have been accentuated by the high-concentrate diet offered.

In contrast to work reported with rats (Robinson \& Lambourne, 1970), there appears to have been an effect on body protein in this study. The increased rate of retention of protein found in the $T_{3}$ sheep is quite close to being statistically significant. This apparent increase in protein may actually be a reflexion of the increase in fat-free EBW. Fig. 4, in which empty-body protein is plotted against fat-free EBW, illustrates that 


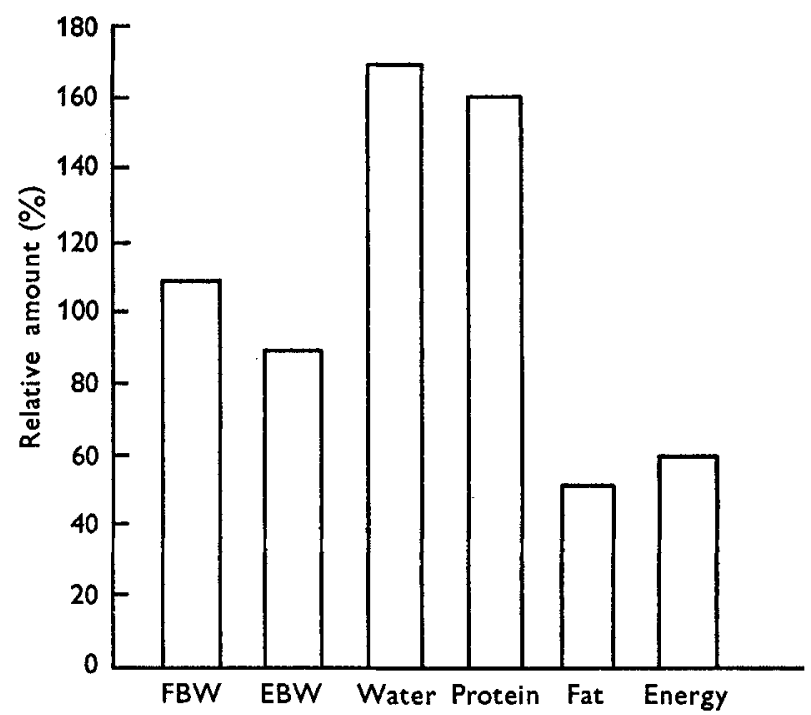

Fig. 5. The relative amounts of the body components regained by $\mathrm{T}_{3}$ realimented animals (normal growth followed by weight loss followed by regrowth) expressed as a percentage of the loss sustained by $\mathrm{T}_{2}$ animals (normal growth followed by weight loss). FBW, full-body-weight; EBW, empty-body-weight.

the normally close relationship which is expected between these two measurements is not disturbed by the treatments imposed. It also indicates that the fat-free EBW of the $T_{3}$ animals are greater than those of other animals in $T_{1}$ and $T_{2}$ at similar EBWs. The fat-free EBW is the sum of weights of body water, protein and ash. Results in Table 3 indicate that, as expected, the total weight of ash increased as the animals grew, in $T_{1}$ group. There were no significant changes in ash contents of the animals in $\mathrm{T}_{2}$ or $\mathrm{T}_{3}$ groups, however. The increase in fat-free EBW, therefore, in the animals in $\mathrm{T}_{3}$ group must be due to the increase in water and, possibly, protein. Since Fig. 4 indicates that the relation between protein and fat-free EBW was not disturbed in $T_{3}$ group it also indicates that the protein content of the bodies of the animals on this treatment had increased.

Fig. 5 illustrates the amounts of the several components regained in $\mathrm{T}_{3}$ group as a percentage of the quantities lost in $T_{2}$ group. Since the sheep slaughtered in $T_{3}$ group were subjected to the same body-weight changes as those slaughtered in $\mathrm{T}_{2}$ group it is assumed that the various body components of the $\mathrm{T}_{3}$ animals underwent similar changes while on the latter treatment. Hence Fig. 5 may be said to indicate the percentage of the loss of a component during weight reduction which was regained during refeeding. On this basis the values for water, protein, fat and energy are 170 , 160, 52 and $58 \%$, respectively. These results are in qualitative agreement with those of Reid et al. (1968) and Keenan \& McManus (1969) with sheep, as well as those of Barnard et al. (1969) with humans, and again support the hypothesis that animals subjected to weight loss and regrowth contain more protein and water and less fat than continuously grown controls.

The reason for the apparent discrepancy between these results and those reported 
by Wilson \& Osbourn (1960), Meyer \& Clawson (1964) and Robinson \& Lambourne (1970) is unknown, but it may be related to factors such as the severity of the dietary restriction and the methods used in estimating body composition. Wedgewood (1963) has shown that the specific gravity of a fat-free eviscerated carcass may decrease with increases in fat-free carcass weight and water content. Both of these changes have been shown to occur in the present study in animals which have undergone weight loss and repletion, as well as in humans (Barnard et al. 1969). Specific gravity measurements for estimating body fat, as employed in the work of Meyer \& Clawson (1964), might over-estimate the fat content of such animals.

The results in Table 4 indicate that a portion of the compensatory growth exhibited by the $\mathrm{T}_{3}$ animals is the result of an increase in gut contents. The average weight of the gastrointestinal tract contents of the $\mathrm{T}_{3}$ animals was $24 \%$ greater than that of the $\mathrm{T}_{1}$ controls. This increase in gut contents is also demonstrated in Fig. 5 which shows that, although $110 \%$ of the FBW lost by $\mathrm{T}_{2}$ animals was regained by $\mathrm{T}_{3}$ animals, only approximately $90 \%$ of the EBW was regained. These differences are attributable to the increase in weight of the gastrointestinal contents.

\section{Adipocyte size and numbers}

The relationship between body fat and empty-body-weight is curvilinear and there is some speculation as to whether the lipid is deposited solely in adipose cells which have been present since early postnatal life (Knittle \& Hirsch, 1968; Salans, Knittle \& Hirsch, 1968; Hirsch \& Han, I969) or if, when the body contains a certain proportion of fat, new adipocytes may be developed for additional lipid (Hellman \& Hellerstrom, 1961; Enesco \& Leblond, 1962; Pitts, 1963; Durand, Fauconneau \& Penot, 1965). Using the procedure already described, perirenal adipose tissue samples were analysed for average adipocyte size and numbers of cells per $\mathrm{g}$ adipose tissue. The results, which are presented above, were analysed according to Duncan's new multiple range test (Steele \& Torrie, 1960). The sheep used were chosen to provide wide treatment differences if such were present. The cells from group 4 animals were the largest $(152 \pm 4 \mu \mathrm{m})$. Adipocytes in the animals of group ro $(143 \pm 4 \mu \mathrm{m})$ had not reached the previous size of those in group 4 by the time the animals reached their slaughter weight, indicating again that they had less fat than group 4. Differences in mean diameters were significant $(P<0.05)$ between the groups at $50 \mathrm{~kg}$ and $7 \mathrm{r} \mathrm{kg}$ FBW but they were not significant between groups at similar body-weights.

There was considerable variability in the number of fat cells per $g$ adipose tissue and no evidence could be found for additional cell production with increased fatness. The average number of cells per $g$ tissue from the sheep in the groups studied was $3.9 \pm 0.5 \times 10^{5}$.

The results reported here have provided additional evidence for the hypothesis that animals, at certain stages of growth, if subjected to weight reduction and regrowth, may accumulate more body protein than they do during growth without interruption. At the same time, these bodies will retain more water and less fat. How the normal growth mechanisms are altered is not known, but it appears that less lipid is deposited 
in the cells of adipose tissue during the period of regrowth than is deposited during normal growth.

This work was partly supported by the National Institute of Arthritis and Metabolic Diseases, U.S. Public Health Service, Bethesda, Maryland, USA, Research Grant AM-02889 NTN.

\section{REFERENCES}

Andrews, R. P. \& Ørskov, E. R. (1970). \%. agric. Sci., Camb. 75, г9.

Barnard, D. L., Ford, J., Garnett, E. S., Mardell, R. J. \& Whyman, A. E. (1969). Metabolism 18, 564. Bull, L. S. (Ig6g). Effect of acetic acid on energy metabolism and body composition of sheep. PhD Thesis, Cornell University, Ithaca, New York.

Burton, J. H. \& Reid, J. T. (1969). F. Nutr. 97, 5 r 7.

Durand, G., Fauconneau, G. \& Penot, E. (1965). Annls Biol. anim. Biochim. Biophys. 5, I63.

Enesco, M. \& Leblond, C. P. (1962). F. Embryol. exp. Morph. ro, 530.

Hellman, B. \& Hellerstrom, C. (196r). Acta path. microbiol. scand. 51, 347.

Hirsch, J. \& Gallian, E. (1968). F. Lipid Res, 9, I Io.

Hirsch, J. \& Han, P. W. (1969). F. Lipid Res. 1o, 77.

Keenan, D. M. \& McManus, W. R. (1969). F. agric. Sci., Camb. 72, I39.

Knittle, J. L. \& Hirsch, J. (1968). F. clin. Invest. 47, $209 \mathrm{I}$.

Lofgreen, G. P. \& Otagaki, K. K. (1960).F. Anim. Sci. r9, 392.

McManus, W. R., Reid, J. T. \& Donaldson, L. E. (1972). F. agric. Sci., Camb. 79, I.

Meyer, J. H. \& Clawson, W. J. (I964). F. Anim. Sci. 23, 214.

Ørskov, E. R., McDonald, I., Fraser, C. \& Corse, E. L. (1971).F. agric. Sci., Camb. 77, 35 I.

Paladines, O. L., Reid, J. T., Bensadoun, A. \& Van Niekerk, B. D. H. (I964). F. Nutr. 82, I45.

Pitts, G. C. (1963). Ann. N.Y. Acad. Sci. rmo, I I.

Reid, J. T., Bensadoun, A., Bull, L. S., Burton, J. H., Gleeson, P. A., Han, I. K., Joo, Y. D., Johnson, D. E., McManus, W. R., Paladines, O. L., Stroud, J. W., Tyrrell, H. F., Van Niekerk, B. D. H. \& Wellington, G. W. (1968). Publs natn. Acad. Sci., Wash. no. I 598, p. I9.

Reid, J. T., Bensadoun, A., Paladines, O. L. \& Van Niekerk, B. D. H. (1963). Ann. N.Y. Acad. Sci. I10, 327 .

Reid, J. T., Wellington, G. H. \& Dunn, H. O. (I955). F. Dairy Sci. 38, I 344.

Robinson, D. W. \& Lambourne, L. J. ( 1970 ). Growth 34, 235.

Salans, L. B., Knittle, J. L. \& Hirsch, J. (r968). F. clin. Invest. 47, I 53.

Steele, R. G. D. \& Torrie, J. H. (1960). Principles and Procedures of Statistics. New York: McGrawHill Book Co.

Tulloh, N. M. (1963). In Symposium on Carcass Composition and Appraisal of Meat Animals p. 5 [D. C. Tribe, editor]. Melbourne: CSIRO.

Wedgewood, R. J. (1963). Ann. N.Y. Acad. Sci. 110, 141.

Wilson, P. N. \& Osbourn, D. F. (I g60). Biol. Rev. 35, 324. 